NBER WORKING PAPER SERIES

TECHNOLOGICAL SUPERIORITY AND THE LOSSES FROM MIGRATION

Donald R. Davis

David E. Weinstein

Working Paper 8971

http://www.nber.org/papers/w8971

NATIONAL BUREAU OF ECONOMIC RESEARCH

1050 Massachusetts Avenue

Cambridge, MA 02138

June 2002

We are grateful to Alan Deardorff and James Harrigan for helpful comments, to Joshua Greenfield for research assistance, and to the Center for Japanese Economy and Business for support. The views expressed herein are those of the authors and not necessarily those of the National Bureau of Economic Research.

(C) 2002 by Donald R. Davis and David E. Weinstein. All rights reserved. Short sections of text, not to exceed two paragraphs, may be quoted without explicit permission provided that full credit, including (C) notice, is given to the source. 
Technological Superiority and the Losses from Migration

Donald R. Davis and David E. Weinstein

NBER Working Paper No. 8971

June 2002

JEL No. F2, J6, F1

\begin{abstract}
Two facts motivate this study. (1) The United States is the world's most productive economy. (2) The US is the destination for a broad range of net factor inflows: unskilled labor, skilled labor, and capital. Indeed, these two facts may be strongly related: All factors seek to enter the US because of the US technological superiority. The literature on international factor flows rarely links these two phenomena, instead considering one-at-a-time analyses that stress issues of relative factor abundance. This is unfortunate, since the welfare calculations differ markedly. In a simple Ricardian framework, a country that experiences immigration of factors motivated by technological differences always loses from this migration relative to a free trade baseline, while the other country gains. We provide simple calculations suggesting that the magnitude of the losses for US natives may be quite large- $\$ 72$ billion dollars per year or 0.8 percent of GDP.
\end{abstract}

Donald R. Davis

Department of Economics

Columbia University

420 West 118th Street

New York, NY 10027

and NBER

drd28@columbia.edu
David E. Weinstein

Department of Economics

Columbia University

420 West 118th Street

New York, NY 10027

and NBER

dew35@columbia.edu 


\section{Technological Superiority and the Losses From Migration}

\section{Technology, Factor Flows, and Income Losses}

Arguably the distinctive feature of the United States economy in a global context is the high level of its technology. Whether measured in the aggregate or at the level of the industry, US technology frequently figures as the most productive in the world, often by a considerable margin. This productivity, naturally, not only delivers high income to natives of the United States, but also influences decisions over the international flow of productive factors to the US economy.

A striking fact is the breadth of productive factors with net inflows to the United States. One might expect, on simple factor abundance grounds, that unskilled labor might find advantage in entering the United States. And so it does. Yet highly skilled labor also finds it advantageous to enter the United States. And the US has been a net capital importer for decades. ${ }^{1}$ One imagines that if land were free to migrate, a great deal of it might seek to move to the US as well.

The study of these international factor flows is almost always considered case by case. There are very good reasons for doing so, since the relevant agents, objectives and constraints vary considerably across these problems. However, the remarkable fact that such a broad array of productive resources desires to locate in the United States suggests that the logic is deeper than may be captured in the one-at-a-time approaches.

The superiority of US technology provides a parsimonious and plausible hypothesis to account for the attraction of the US location to such a broad array of factors. However, it is important to recognize that when factor movements are motivated

\footnotetext{
${ }^{1}$ For all the talk of the "twin deficits," net capital inflows continued into the United States even as the US government budget moved into surplus in the late 1990s.
} 
by technological differences, both the positive and normative dimensions of these flows may differ significantly from more conventional approaches.

The conventional approach considers discrete inflows of a single factor to an economy. It then calculates an immigration surplus as the economy moves down the marginal product curve for the migrant factor. Much of the discussion concerns the magnitude of this surplus and whether fiscal considerations offset or reverse the sign of the net surplus. ${ }^{2}$

The conventional approach does not always make explicit the origins of factor price differences that motivate migration. When these are made explicit, the basis is usually differences in relative factor abundance. However, this immediately runs into a problem. In such a framework, if one factor receives a higher return in the US economy (say unskilled labor), then some other factor (e.g. skilled labor) must receive less - so want to leave the US economy. This is at odds with the observation that all factors seek to enter the US.

This puzzle has an obvious fix. This is to allow international productivity differences that lead all factors to be more productive in the US, and so lead all factors to desire to enter such a highly productive economy. ${ }^{3}$ As a first pass of analysis, this suggests some economy from treating the multiple factors as a single composite factor. And this leads directly to a variant of the standard Ricardian trade model, now amended to allow for migration, as a setting in which to examine the consequences for a country of immigration when this is motivated by technological advantage.

\footnotetext{
${ }^{2}$ For example, see Borjas (1995), Figure 1; Lalonde and Topel (1997), Figure 1; or Razin and Sadka (2001) Figure 1.

${ }^{3}$ Indeed, recent research by Lutz Hendricks (2002) strongly supports the hypothesis that national TFP differences matter for the wage differences motivating labor migration.
} 
The key analytic insight can be stated simply. When immigration is motivated by technological advantages, natives in the country that receives immigrants always lose relative to a baseline with free trade. This is very much at odds with the presumption in the literature that considers inflows one factor at a time. Nonetheless, the logic of the result is quite simple. Even in autarky, a country enjoys the fruits of its own highly productive technology. When the country opens to trade, having a monopoly on its own technology is a crucial element of comparative advantage and gives rise to gains for this economy. Immigration, in this context, amounts to an erosion of this monopoly power. Although immigration motivated by technological advantage shifts out the world production opportunities set, the country experiencing the immigration always loses. Trade arising due to technological differences is a source of mutual gain. However, when free trade is in place, migration due to technological differences is not a source of mutual gain. World income rises, but more than all of this is captured by natives of the country of emigration. Natives of the country experiencing immigration lose.

Given the simplicity of these analytic results, and the plausibility of the underlying assumptions, it is surprising that this approach has previously figured almost not at all in the discussions of factor flows. Although the Ricardian model is nearly always the first model of trade that we teach students, it is almost never used to discuss migration issues. We have found only two references. Findlay (1982) discusses the possibility of native losses from migration in a paper on "International Distributive Justice," and Daniel Trefler (1997) does likewise amidst a catalog of models that might be used to think about these issues. Both solve the model and recognize that immigration creates a loss for the receiving country. We go beyond their work in several respects. The 
first is simply to grasp that coordinated inflows of a wide range of productive factors unskilled labor, skilled labor, and capital - would make an interpretation of "labor" in the Ricardian model as a composite factor quite reasonable. The second is to see that this is in fact a good description of the US experience in recent decades. The third is to use these insights to develop empirical applications that allow us to quantify the losses for US natives. ${ }^{4}$

Trade theorists have a long tradition of discussing the possibility of losses from factor accumulation or international factor movements, as in Jagdish N. Bhagwati (1958), or Gene M. Grossman (1984). Even a graduate textbook treatment of the interaction of trade and factor mobility has been developed in Kar-Yiu Wong (1995). Yet there seems not to have been a recognition in the field that the Ricardian model might be the right framework for thinking about the consequences of such factor inflows to the US economy. This might reflect the availability of what appear to be more general models of factor flows, a tendency to think about these flows one at a time, and the fact that until recently empirical analysis played a relatively small role in the field.

Empirical consideration of the international movement of labor has attracted some of the top talent among labor economists. This includes outstanding work by Borjas $(1995,2001)$, who is one of the first to take seriously the task of quantifying the aggregate impact of immigration on US income. It also includes a wealth of work surveyed by Lalonde and Topel (1997) and Friedberg and Hunt (1995). There are two

\footnotetext{
${ }^{4}$ Trefler (1997, p. 11) seems to have on his mind only inflows of low-skilled labor, writing "Since immigrant and native labor compete head on for the same jobs at the same wages, the home country can only absorb the immigrants in low productivity industries that spring up in response to immigration. One should think of these industries as garments or citrus fruit which would disappear in the absence of migrant workers." By contrast, we think of the inflow of a broad range of factors as potentially expanding output in many or all sectors.
} 
factors that have tended to distract labor economists from the results we highlight. The first is simply that they have focused on labor flows, not all factor flows. ${ }^{5}$ The second is that distinct methodological traditions have acted as barriers between the labor economists who have thought hardest about the empirics and the theoretical traditions in international trade that are a key part of the approach developed here. In any case, the labor economists must be given great credit for being the first to quantify the impact of labor flows.

Finally, those who think about international capital flows have likewise neglected the issue. The classic model of MacDougall (1960) on the consequences of capital inflows delivers precisely the type of "immigration surplus" featured in the labor literature, in this case with capital inflows taking the place of labor inflows. Again, one reason for neglect of the issues we raise is specialization by field, so that those economists who think about capital flows rarely concern themselves with labor flows. ${ }^{6}$

In sum, our approach to analyzing these factor flows seems not to have been carried out previously in large part because the analytic and methodological elements key to these effects have been divided across fields that have too little communication.

This paper sets out a simple framework for exploring these issues. Section II considers the gains and losses from immigration within the classic model of Dornbusch, Fischer, and Samuelson (1977). Section III extends this to consider the case in which labor quality differs across countries. Section IV establishes our rationale for using the

\footnotetext{
${ }^{5}$ In this case, the exceptions tend to prove the rule. For example, Lalonde and Topel (1997) do briefly discuss what would happen if capital moved into the US in the same proportion as labor, but conclude that it would then leave incomes unchanged due to constant returns to scale, ignoring the possibility of terms of trade losses that we identify.

${ }^{6}$ A rare exception is Razin and Sadka (2001), who do discuss both Labor and Capital Flows. Nonetheless, having taken advantage of the symmetry of the problems in analytics when considered one at a time, they then move to discuss the issues wholly separately.
} 
Ricardian model as a framework for analyzing factor immigration to the US, documenting the dimensions and magnitude of US technological superiority and of the inflows themselves. Section $\mathrm{V}$ provides empirical exercises that establish baseline quantification of the losses to US natives of these factor inflows. These exercises build most importantly on Acemoglu and Ventura (2002) and on Harrigan (1997). We also consider some robustness checks. Section VI concludes.

\section{Migration in the Dornbusch-Fischer-Samuelson Model}

We consider a world with two countries, home and foreign (with foreign variables indicated by an asterisk). The world labor force $L^{W}$ is fixed and distributed among the home and foreign countries so that:

$$
L+L^{*}=L^{W}
$$

For the moment, we assume there are no possibilities of migration.

There exists a continuum of goods indexed by $z \in[0,1]$. Let output of $z$ at home be $y(z)$ and output of $z$ abroad be $y^{*}(z)$. Then the corresponding production functions are:

$$
\begin{gathered}
y(z)=A(z) L(z) \\
y^{*}(z)=A^{*}(z) L^{*}(z)
\end{gathered}
$$

$A(z)$ and $A^{*}(z)$ are the respective productivities. We order the goods according to decreasing degree of home comparative advantage and for simplicity assume this ordering is strict. Hence

$$
\text { If } z<z^{\prime} \text {, then } \frac{A(z)}{A^{*}(z)}>\frac{A\left(z^{\prime}\right)}{A^{*}\left(z^{\prime}\right)}
$$


Goods and factor markets are perfectly competitive. Free entry excludes the possibility of economic profits, so that for any good $\mathrm{z}$, the wage equals the value marginal product in the market where it is produced:

$$
\begin{aligned}
& w=A(z) p(z) \text { if } z \text { is produced at home. } \\
& w^{*}=A^{*}(z) p(z) \text { if } z \text { is produced in foreign. }
\end{aligned}
$$

For any good $\mathrm{z}$, the relative productivities in the goods establish the relative wage at which the good could be competitively produced in both countries. This defines a functional relation over $\mathrm{z}$ between relative wages and relative productivities that is derived by taking the ratio of the equations in (5). We assume the goods are traded freely, so that $p(z)$ is the common goods price. This yields the function:

$$
\rho(z) \equiv \frac{A(z)}{A^{*}(z)}
$$

Note that $\rho^{\prime}(z)<0$, indicating decreasing home comparative advantage.

$$
\text { If we knew the equilibrium relative wage } \frac{w}{w^{*}} \text { then we could identify which goods }
$$

are produced in which country. Suppose for a moment that the equilibrium relative wage is such that some good $\tilde{z}$ can be profitably produced in both locations. Then, since home's comparative advantage is strongest in low index goods, it must be the case that goods produced at home, for which $z<\tilde{z}$,

$$
\frac{A(z)}{A^{*}(z)}>\frac{w}{w^{*}}
$$

Correspondingly, since foreign's comparative advantage is strongest in high index goods, it must be the case that goods produced in foreign, for which $z>\tilde{z}$,

$$
\frac{A(z)}{A^{*}(z)}<\frac{w}{w^{*}}
$$


Equations (7) and (8) will be very important when we derive the welfare consequences of migration. But first we show how the equilibrium relative wage is established.

We assume that consumers in each country have identical log linear preferences, so that expenditure shares on each good are fixed and common across countries. Let this share for good $z$ be given by $b(z)$. We require that $\int_{0}^{1} b(z) d z=1$. We can also define the share of spending on goods in the range $[0, z]$ to be given by:

$$
\theta(z)=\int_{0}^{z} b\left(z^{\prime}\right) d z^{\prime}
$$

This allows us to define a market clearing equation. Assume for a moment that good $z$ defines a boundary between goods produced at home (low index goods in which home has comparative advantage) and those produced abroad. Then $\theta(z)$ is the share of consumer spending falling on goods produced in the home country. Home and foreign income (hence spending) are $w L$ and $w^{*} L^{*}$ respectively. Here market clearing can be expressed as a balanced trade condition:

$$
[1-\theta(z)] w L=\theta(z) w^{*} L^{*}
$$

This can also be expressed as a relation between the relative wage and the boundary good consistent with market clearing:

$$
\omega(z) \equiv \frac{\theta(z)}{[1-\theta(z)]} \frac{L^{*}}{L}
$$

Note that $\omega^{\prime}(z)>0$.

The relations $\rho(z)$ and $\omega(z)$ can be plotted in the space of relative wages and $z$. Their intersection defines the boundary good $\tilde{z}$ and share of spending on products 
produced in the home country $\theta(\tilde{z})$ consistent with trade according to comparative advantage and market clearing. Absent migration, this determines equilibrium, as in Figure 1.

We now turn to consider the equilibrium when costless migration is allowed in addition to trade. The first observation is that costless migration will insure that inferior technologies are never employed. Production will be according to absolute advantage. Moreover, labor moves to equate wages. By equation (11), adjustment in the distribution of the world labor force across countries will shift $\omega(z)$ to achieve equal wages.

It is worth pausing for a moment to note that allowing labor to migrate freely expands the feasible world production set any time, as here, that technologies across countries are not identical. With perfect competition in all markets and an expanded feasible world production set, we can be assured that world income will go up (at least weakly) with the possibility of migration.

This framework gives us two cases to consider. The first is one in which each country has an absolute advantage in an interval of goods. This is depicted in Figure 2, and without loss of generality, we assume that the initial distribution of world labor led country 1 to have a higher relative wage. Then enough foreign labor moves to the home economy to insure that $\omega(z)$ and $\rho(z)$ cross where the wages are equated.

The key question to resolve is who gains or loses from this migration. Note that with an expanded world income, it is feasible for both to gain. If lump sum taxes were available and employed, both could gain again. Unfortunately, since they are in practice infeasible either administratively or politically, we look only at gains and losses through the market. 
In the Ricardian framework, it is convenient to derive a real wage separately in terms of the price of typical goods produced at home and abroad. These allow us to make the appropriate inferences about welfare.

For a good produced at home, equation (5) tells us that the wage equals the value marginal product, or $w=p(z) A(z)$. It is very useful to rearrange this to define a real wage in terms of such a good:

$$
\frac{w}{p(z)}=A(z) \text { if } z \text { is produced at home. }
$$

That is, the real wage in terms of $z$ for a good produced at home is just given by the home productivity in $z$. Moreover, since producing a good oneself is always an option, the home productivity $A(z)$ is also a lower bound on the home real wage in terms of this good.

If a good $\mathrm{z}$ is produced abroad, then $w^{*}=p(z) A^{*}(z)$. The home real wage in terms of such a good is:

$$
\frac{w}{p(z)}=\left[\frac{w}{w^{*}}\right] A^{*}(z) \text { if } z \text { is produced in foreign. }
$$

Equation (13) reveals that for a good produced in foreign, the home real wage depends on the factoral terms of trade, $\frac{w}{w^{*}}$, and the foreign productivity $A^{*}(z)$.

The pattern of production and trade in the Ricardian model depends on a comparison of relative productivities and relative wages. From equation (7) above, a good will be produced at home just in case $\frac{A(z)}{A^{*}(z)}>\frac{w}{w^{*}}$. In the reverse case it will be produced in foreign. It is convenient to rearrange this equation to link the pattern of 
production and trade to the real wages for the respective goods. Multiplying through, we have that a good is produced at home just in case:

$$
A(z)>\frac{w}{w^{*}} A^{*}(z)
$$

These terms compare precisely the real wages developed in equations (12) and (13) above. That is, a good is produced at home just when the real product wage offered there exceeds that available through trade.

This also makes it very easy to understand the impact of migration on home real wages relative to the free trade baseline. By hypothesis, the initial relative wage of home was $\frac{w_{0}}{w_{0}^{*}}>1$ and with free migration, this factoral terms of trade falls to $\frac{w_{1}}{w_{1}^{*}}=1$. With inflows of labor to the home economy, we showed above that the range of goods produced at home expands. Hence there are at most three types of goods.

(i) If $\operatorname{good} z$ is produced at home before and after migration, then

$$
\frac{w}{p(z)}=A(z) \text { is unchanged }
$$

(ii) If good $z$ is initially produced in foreign, but switches to home after the migration, and recalling that $\mathrm{A}(\mathrm{z})$ is a lower bound for a home product wage,

$$
\frac{w}{p(z)} \text { falls from } \frac{w_{0}}{w_{0}^{*}} A^{*}(z) \text { to } A(z)
$$

(iii) If good $z$ is produced in foreign both before and after migration, and recalling that initially $\frac{w_{0}}{w_{0}^{*}}>1$, while $\frac{w_{1}}{w_{1}^{*}} \equiv 1$,

$$
\frac{w}{p(z)} \text { falls from } \frac{w_{0}}{w_{0}^{*}} A^{*}(z) \text { to } A^{*}(z)
$$


In short, the home country that experiences immigration loses for sure. Its wage is unchanged in terms of the type (i) goods that it produced both before and after migration. But its real wage falls in terms of both type (ii) and type (iii) goods, those newly produced in home due to the migration and those goods produced by the foreign workers who remain in foreign.

The foreign country that provides the immigrants gains for sure. The simplest way to see this is simply to recall that migration leads world income to rise and this must accrue to someone. If the home labor lost, it must be because the foreign labor reaped more than all of the world income gains. We could also do the good-by-good analysis as before. This would reveal that foreign labor neither gains nor loses in terms of the type (iii) goods it produced before and after. Yet it experienced real income gains in terms of both goods that it previously imported and those newly produced in the home country.

Having considered the case in which each country had technical superiority in an interval of goods, we now can very easily analyze the case in which one country (say home) has technological superiority in all goods. When migration is not possible, the two countries trade according to comparative advantage. When migration is possible, the inferior foreign technologies simply cease to be employed. Again, we could analyze the movement of wages in terms of the prices of goods initially produced in each of the two countries. However, a shortcut provides the desired answers more quickly.

Note that when foreign labor has access to the superior home technology, the relative prices of all goods are determined simply by the relative productivities of home technology, exactly as in the home autarky equilibrium. In fact the equilibrium with migration effectively returns home labor to the autarky equilibrium. Since home labor 
initially enjoyed gains from trading with the foreign country due to comparative advantage, this return to effective autarky means that home labor loses for sure. Foreign likewise may be thought of as having returned to a type of autarky, but it is an autarky with the superior home technology, so that foreign labor experiences substantial gains from migration. Again, migration shifts out world production possibilities and with perfect factor markets raises world income. But, relative to the trading equilibrium, more than all of the incremental world income from migration accrues to foreign labor. Home labor loses. ${ }^{7}$

\section{Non-Homogeneous Labor}

The foregoing has assumed that home and foreign labor are identical provided they have access to the same nation-specific technology. However, we know that in the United States, immigrant labor has neither the same geographical nor occupational distribution as natives. ${ }^{8}$ Moreover, immigrants on average do not earn as much as natives when controlling for other relevant characteristics. Since the empirical exercises to follow must confront these non-homogeneities, we need an analytic framework to determine an appropriate way to do so.

\footnotetext{
${ }^{7}$ These results have been developed within the context of the Dornbusch-Fischer-Samuelson model, with its restrictive assumptions on demand, the existence of a continuum of goods, and that the degree of comparative advantage is itself continuous. These assumptions are convenient for the transparency of the analysis. However, by analogy with the results developed here, it would be straightforward to demonstrate that none of these restrictions is necessary.

${ }^{8}$ In what follows we ignore the issue of the geographical concentration of immigrant labor. However, we will note that an extensive discussion among labor economists has already considered the importance of this, noting that the opportunities of other potential internal migrants to alter plans and of producers to shift production mix to adjust to international migrant settlement patterns suggests that the geographical impact may be quite limited. This seems sensible in an appropriate long run. Borjas (1994, p. 1700) notes that the puzzling fact is that this equilibration in the case of international migrants seems to happen extremely rapidly.
} 
The essential analytic points can be set out in a very simple framework. For this exercise, let $L^{F}$ be the equilibrium quantity of foreign labor that enters the home economy. Let $\varphi(z) \leq 1$ be the productivity of foreign labor relative to home labor when it has access to the home technology. In other words, allow for the possibility that foreign labor is less productive than home labor at producing a good $z$ even when it has access to the home technology. Hence, for foreign labor employed in the home country,

$$
y(z)=\varphi(z) A(z) L^{F}(z)
$$

Output for home labor remains as in Equation (2).

For simplicity, divide the goods produced in the home country into two groups $Z^{+}$and $Z^{-}$distinguished by the relative productivity of foreign labor, where $\varphi(z)$ is assumed constant within each group and $\varphi(z)>\varphi\left(z^{\prime}\right)$ if $z \in Z^{+}$and $z^{\prime} \in Z^{-}$. For the moment, we can simplify further by assuming $\varphi(z)=1$ for $z \in Z^{+}$(so home and foreign labor are equally productive in these goods).

For our purposes, the interesting case to consider is one in which, in equilibrium, home labor is active in producing both types of goods. In this case, immigrant labor will be active only in producing $Z^{+}$-type goods, since the wage on offer to it there will be equivalent to the native wage while it would be lower were they to be employed in $Z^{-}$type goods.

This case has two features that are especially important for us. First, immigrant labor is highly concentrated, producing only $Z^{+}$-type goods. Second, this concentration is wholly inconsequential for the equilibrium of the real economy. Since wages of native and immigrant labor are already equalized, there would be no incentive for either type to change sectors even if there were no productivity gap in the remaining goods. In this type 
of equilibrium in which native labor remains active in all sectors and immigrant labor only in some, one can treat the two as identical even if there are productivity differences that prevent the immigrant labor from moving into other sectors.

This can be readily extended to the case in which home labor has a productivity advantage in both types of goods. In that case, $\varphi(z)<1$ for $z \in Z^{+}$. So long as the productivity gap remains smaller in $Z^{+}$-type goods and native labor remains active in both sectors, immigrant labor will be concentrated in the $Z^{+}$-type goods. Changes in immigrant labor that do not shift us from this equilibrium can be treated as if each immigrant delivers $\varphi(z)$ units of labor when measured in native equivalents. This rationalizes a world in which immigrant labor is concentrated by productive sector and in which there exists a wage gap between immigrants and natives. Nonetheless, it says that we can treat immigrant and native labor as equivalents provided we make the appropriate conversion to efficiency units.

\section{The US Productivity Advantage and Factor Inflows}

The empirical segment of this paper has two objectives. The first is to establish on a prior basis the reasonableness of our use of the Ricardian model as a framework for analyzing factor inflows to the US economy. The second is then to use this framework, and simple variants, to calculate the impact of these flows on the US.

The Ricardian framework is special in two dimensions. The first is that technological differences are the foundation for observed factor flows. The second is that the Ricardian model relies on a single composite factor "labor". For this to be a reasonable framework for our exercise, we would like to verify the plausibility of these 
assumptions. For the first, we would like to confirm that the US has productivity

advantages that could be the origin of these flows. For the analytics based on a composite factor, we would like to see that the entry patterns to the US of mobile factors are at least broadly similar across different types of factors. Measuring these factor inflows will also then serve as an input to our calculation of the impact on the US.

\section{A. US Productivity Advantages}

The US enjoys a large productivity advantage over virtually all other countries in the world. Table 1 presents estimates from Islam (1995 and 2001) of total factor productivity (TFP) for a large sample of countries. As the data reveal, many developing countries have TFP levels less than 20 percent of the US level. In some extreme cases, productivity in developing countries is less than 5 percent that of the US. In these data only Hong Kong and Canada have TFP levels higher than that of the US. While there is a rich TFP literature that has produced a variety of point estimates for individual countries [see e.g. recent work by Hall and Jones (1996)], all studies conclude that TFP in the US is among the highest in the world. ${ }^{9}$

Hendricks (2002) provides an alternative approach that arrives at a similar conclusion. He draws on observations of the earnings of immigrants to the US from various countries as one input in a decomposition of the sources of cross-country income differences. If differences in the quality of human capital were to explain the vast cross-

\footnotetext{
${ }^{9}$ While differences in aggregate TFP suffice to establish a motive for migration and would be fully adequate to the story we tell here, trade according to comparative advantage requires as well that there be variation at the product level in the TFP gap. The best existing evidence is the work of Jorgenson and various co-authors, as for example in Jorgenson and Kuroda (1990), which shows substantial variation in relative TFP at the industry level even for relatively rich countries. Moreover, Harrigan (1997) shows that this industry variation in TFP also affects patterns of international specialization.
} 
country differences in income, then there would need to be very large gaps in wages between immigrants and US natives - of a magnitude that we do not observe. He concludes that to make sense of the much smaller actual gaps, even after accounting for other cross-country differences, one must rely on large differences in TFP - precisely the mechanism that we rely on in this paper as the motivation for factor migration.

\section{B. Contribution of Immigration to the US Labor Force}

The US census provides the most accurate numbers on the percent of the US labor force that was born abroad. The Census Bureau tries hard to make adjustments for undercounting of illegal immigrants. The Census Bureau reports that the proportion of foreign born as a share of the US population in 1998 was 9.8 percent [OECD (2001)]. As it turns out, the contribution of the foreign born to the US labor force is even greater than its contribution to US population because immigrants have higher labor force participation rates than natives. As a result, in 1998 fully 11.7 percent of the US labor force was comprised of people born outside of the US. This is the point estimate that we will use throughout the remainder of the paper.

Although census data is superior to INS (2002) data in terms of understanding what share of the US labor force comes from abroad, INS data is useful in understanding the timing and sources of immigrant inflows. ${ }^{10}$ The US immigrant population is largely the result of a dramatic increase in immigration to the US in recent decades. As we can

\footnotetext{
${ }^{10}$ One must be careful in comparing the INS data with the census data because gross legal immigrant inflows into the US are not the same thing as net flows of immigrants. The INS identifies two main sources of error. First the census bureau estimates that in the 1990's approximately 220,000 foreign-born residents and 48,000 native-born residents emigrated from the US each year. On the other hand, the INS estimates that 275,000 entered the US illegally each year. Surprisingly, these numbers are quite similar, suggesting net inflows in the last decade were quite similar in magnitude to the level of legal immigration.
} 
see from Table 2, legal immigration rose from approximately 250,000 per year in the 1950 's to close to one million per year in recent decades. In addition to the large absolute inflows, immigrants have accounted for an increasing share of US population growth. Between 1950 and 1998, the US population rose approximately 80 percent, growing from 152 million to 271 million. Using legal flows of immigrants as a proxy for net flows, the share of migrants in US population growth rose from approximately 9 percent in the 1950's to around 37 percent since 1980. Much of this reflects the fact that legal immigrant inflows as a share of the existing population rose from around 0.1 percent to 0.3 percent per year. This, coupled with declining fertility in the native population, accounts for the growing relative importance of immigration in US population growth.

A second striking feature of the INS data is the sources of immigration. Only 5.5 percent of the legal immigrants to the US in 1999 came from countries whose TFP as measured by Islam (2001) was at least 70 percent as high as that of the US. Moreover, over half of the legal immigrants to the US between 1991 and 1995 came from the Caribbean, Central and South America - countries with typically less than one-third the US TFP level. Other major source countries, such as the Philippines, the Soviet Union, China, India, and Vietnam, have low TFP levels as well.

Taken together, the data reveal that immigration from countries with low TFP levels account for the vast majority of immigration into the US. Moreover, this immigration from low TFP countries accounts for a substantial share of the growth in the US population and labor supply. These facts underscore the Ricardian motivations for migration. 


\section{Composition of Immigrants to the US}

The foregoing has considered the contribution of the foreign born to the US labor force, yet it has not taken account of possible differences in the skill composition of native and foreign born workers. Until 1994, the Current Population Survey contained a question regarding whether or not a worker was born abroad. Based on this, it is possible to examine differences between native and foreign-born educational attainment (see Table 3). The CPS data indicate that immigrants have lower levels of educational attainment. But the differences are not as substantial as one might think. In 1994, 29 percent of foreign-born workers had at least a college degree (16 or more years of education) while 32 percent of US born workers did. At the high skill end, there is a gap, but it is small.

There is a greater difference between immigrants and natives among the lower tiers of educational attainment. While 33 percent of immigrants had less than 12 years of education only 13 percent of native-born people did. This suggests the influx of immigrants is likely to have its biggest relative impact on the factor supply of low skilled workers in the US.

\section{Contribution of Net Capital Inflows to the US Capital Stock}

Factor inflows to the United States have not been limited to labor. In recent decades, the US has experienced large and persistent net capital inflows. These capital inflows have assumed an important and growing role as a share of US gross capital formation. Figure 4 reveals that while there was a small capital outflow from the US in the 1970's, this was reversed in the early eighties. Indeed, for the last two decades, net 
foreign capital inflows financed between 5 and 21 percent of US gross capital formation. $^{11}$

We would like to emphasize that in making this calculation we do not mean to imply that technological advantage is the sole determinant of net capital flows. Rather, we look on national technological advantage as one determinant of the level of investment, which along with other determinants of saving and investment works through the national income accounting to determine the net capital flows. Here we are able only to calculate the impact of actual inflows, not to separate the motivations for these inflows. This notwithstanding, we believe that national technological advantage, per the discussion above, is almost certainly an important component in the joint determination of these net flows.

We can obtain some sense of the importance of these net flows by looking at how much of the US capital stock has been financed from abroad. Capital in year $t$ can be defined as

$$
K_{t}=I_{t} / P_{t}+(1-\delta) K_{t-1}
$$

where $K_{t}$ is the capital stock, $I_{t}$ is gross fixed capital formation, $P_{t}$ is the price of capital equipment and $\delta$ is the deprecation rate.

We define a counterfactual domestically financed capital stock in year $t$ as,

$$
K_{t}^{d}=\left(I_{t}-N K_{t}\right) / P_{t}+(1-\delta) K_{t-1}^{d}
$$

where $N K_{t}$ is the net flow of capital into the US. $K_{t}^{d}$ can be either larger or smaller than the actual capital stock depending on the sign of $N K_{t}$. If it is smaller, then it represents

\footnotetext{
${ }^{11}$ Indeed, by the year 2000 these net capital inflows accounted for one-fourth of US gross capital formation.
} 
the amount of capital that was financed by domestic savers. If it is larger, then it represents how much the US capital stock would have been if net flows of investment funds had not flowed out of the US but rather had been invested domestically.

Finally, we define the foreign financed capital stock as

$$
K_{t}^{f} \equiv K_{t}-K_{t}^{d} .
$$

Implicitly, this decomposition of the actual capital stock into foreign and domestic components assumes that the path of domestically financed investments would have been no different had the US closed its borders to capital inflows. To go beyond this requires a model of this counterfactual, an exercise we do not perform in this paper. Here we assume that domestic investment is unaffected by net foreign capital inflows and view our calculations as a benchmark.

Using data on investment and the price of capital goods from the IMF, we set the capital stock in 1947 equal to zero and calculate the US capital stock using the same depreciation rate (13.3 percent) as in Bowen, Leamer and Sveikauskas (1987) and Harrigan (1997). We then set the domestic capital stock in 1970 equal to our estimate of the US capital stock in that year and calculate the domestic capital stock according to equation (17) and the foreign capital stock according to equation (18). This procedure yields an estimate of the foreign-financed capital stock in 1998 equal to 11.8 percent of the total US capital stock.

\section{E. Reasonableness of the Ricardian Framework}

We stated two criteria at the outset for the reasonableness of our use of the Ricardian framework for examining the consequences of the inflow of factors to the US 
economy. The first criterion is that the US has a productivity advantage that is plausibly a motivation for these factor movements. We saw that this is strongly confirmed by the evidence above on US TFP advantages, which are particularly strong relative to countries that are the main sources for immigration to the US. The second criterion is that it is plausible to treat the factor inflows as if they were a composite factor as per the Ricardian model. This in turn requires that the magnitude of the inflows across factors not have been too different. We saw above that the contribution of the foreign born as a share of the US labor force is 11.7 percent. Under our assumptions, this number is strikingly close to the 11.8 percent estimate of the share of the US capital stock financed by net inflows of foreign capital.

If this were the whole story, then our treatment of the factors as a composite would be strongly confirmed. Of course, we also saw that when we disaggregate labor into different types, there are some differences in composition, especially among the least skilled. We will address this issue of composition more directly below when we turn to a multi-sector account of the impact of these factor flows on output composition and our terms of trade. Nonetheless, the fact that, in broad terms, the inflows of capital and labor are so similar in magnitude seems to us strong reason for taking seriously our Ricardian approach to the consequences of factor inflows as an alternative to the standard approach, which considers inflows only of one factor at a time.

\section{$V$. How Factor Migration Affects the Income of US Natives}

In this section we calculate the impact of these factor inflows on the US economy. In principle, we could generate as many estimates of this impact as there are potential 
models of the US and world economies. Our core results are developed in two steps. The first step focuses purely on the rise of the US scale in the world economy due to immigration and is closest to the macroeconomic literature, as exemplified by Acemoglu and Ventura (2002). The second step supplements this by allowing for greater heterogeneity in labor inflows and output composition, and is closer to the international trade literature, as in Harrigan (1997). We also discuss robustness to alternative assumptions. $^{12}$

\section{A. Macroeconomic Approach}

A first step in estimating the impact of factor migration to the US would merge a simple variant of our Ricardian model above with the $A K$ approach of Acemoglu and Ventura (2002). We can simplify our Ricardian model so that there is a single good produced in each of the US and the rest of the world, but which differ from one another. ${ }^{13}$ As in both our model and that of Acemoglu and Ventura, we will think of only a single composite factor (“capital” for them, "labor" for us). The US technological advantage then gives rise to factor movements that raise output of the US good and contract output of the good produced in the rest of the world. This shift in relative outputs then will have

\footnotetext{
12 The simulations we develop are in the same analytic spirit as those of Borjas, Freeman, and Katz (1997). Borjas (1999, p. 48) argues in support of this approach, noting that "although the factor proportions approach relies on theory, so must any applied economic analysis that wishes to do more than simply calculate correlations. In the end, any interpretation of economic data - and particularly any use of these data to predict the outcomes of shifts in immigration policy_requires a 'story'."

${ }^{13}$ The central results we developed above in Section II are robust to a restriction that the margin of goods produced in each country does not change, as we assume here. Unfortunately, the empirical researcher does not directly observe a change in the margin of goods produced, as the theoretical model of Section II would require. No doubt, some of this change in the margin may be captured by the changing composition of output considered in Section V.B. below.
} 
terms of trade effects and we will use the elasticities estimated in Acemoglu and Ventura to evaluate these.

As noted earlier, our treatment of the factor inflows as a composite is motivated by the fact that the contribution of foreign labor inflows to the US labor force and the contribution of foreign net capital inflows to the US capital stock come in at almost the same level (11.7 vs. 11.8 percent). If we multiply the US labor share by 11.7 percent and the capital share by 11.8 percent, then, we will then translate this into an equivalent proportional increase of 11.8 percent in output of the US good.

At initial prices, this would translate into an equivalent proportion excess supply of US goods in world markets. Adjustment will occur through a deterioration in the US terms of trade. For our calculation, we will use the preferred estimate from Acemoglu and Ventura, in which the elasticity of the terms of trade with respect to GDP is -0.60 . The consequent deterioration in the US terms of trade as a result of the growth implied by these factor inflows is then -7.0 percent.

Before we can calculate the cost to the US economy of this, we need to resolve an ambiguity here. Whether the change in the terms of trade comes through a decline of export prices or a rise in import prices would be immaterial if trade were balanced. However, since the IMF reports that exports were 8 percent and imports 11 percent of US GDP, this could make a difference. Our approach is simply to split the difference, assuming that the change in the terms of trade comes half in the form of a fall in US export prices and half in the form of a rise in US import prices.

Hence our calculation of the lost income via the terms of trade deterioration is of the form: 


$$
\left(\frac{\Delta \mathrm{GDP}}{\mathrm{GDP}}\right) \varepsilon^{\mathrm{T}}\left(\frac{1}{2} *\left[\frac{M+E}{\mathrm{GDP}}\right]\right)
$$

where the first term in parentheses is the change in GDP due to factor inflows, $\varepsilon^{T}$ is the Acemoglu-Ventura estimate of how much GDP growth causes the terms of trade to deteriorate, $M$ is imports and $E$ is exports. This yields an impact in 1998 of 0.7 percent of US GDP or \$58.4 billion dollars.

So far, we have focused on the consequences of the expansion of US output of these factor flows. However, we also need to recognize that their movement leads to a contraction of output of the rest of the world, making foreign output scarcer relative to US output, causing additional deterioration in the US terms of trade. These incremental effects are likely to be smaller than those calculated above precisely because of the lower productivity of factors in the rest of the world. Of the 28 million foreign-born residents of the US, only 16 million are actually in the labor force. Given that the World Bank (1999 WDR) puts the global labor force outside of the US at 2.6 billion workers, this probably only represents a 0.6 percent decline in the number of available workers. In terms of capital we get slightly larger effects. Davis and Weinstein (2002) estimate that 23 percent of the world's capital stock is in the US. Since 11.8 percent of the US capital stock was financed from abroad, the flows imply a 3.5 percent reduction in the capital stock of the rest of the world.

Multiplying these numbers by the US labor and capital shares, we estimate that factor flows from the rest of the world to the US decreased output in the ROW by 1.9 percent. This implies an additional deterioration in the US terms of trade of 1.1 percent, which would cost the US an additional 9.2 billion dollars. Taken together this first step 
in our exercise generates a net income loss to the US from factor migration of 68 billion dollars in 1998 or 0.8 percent of US GDP in that year.

\section{B. Heterogeneous Labor in Multi-Sector Model Approach}

We now supplement this macro approach with elements focused on composition effects. There are two key departures. The first is that we disaggregate our labor variable according to skill class. The second is that we move to a multi-sector model of the US economy. These departures allow us to develop a simple model that builds on Harrigan (1997) to describe the impact on the US net offer to the rest of the world at the initial prices. We then apply terms of trade elasticities at a sectoral level, which we draw from Deardorff and Stern (1986). Again these will allow us to calculate the impact on US incomes of the immigration of these factors, now taking account both of scale and composition effects.

In this exercise, we disaggregate the labor force into three classes, those with a college degree, high school graduates, and high school dropouts. As we noted earlier, the proportion of foreign born in the high educational bracket mirrors reasonably closely that proportion in the native population. However, this is less true at lower educational levels, where natives are more likely to have completed high school and the foreign born to have dropped out. These differences are at least potentially important in our framework because in a multi-sector model they will have a non-uniform effect on the composition of output. In principle this could even improve the US terms of trade if the composition works to principally expand import-competing sectors. By using a multi-sector model and employing the estimates of Harrigan (1997), we can take direct account of these output 
composition effects. Finally, the multi-sector model also allows us to move away from applying a single terms of trade elasticity for composite exports, but rather to allow for different elasticities by sector.

We now discuss our implementation. Let $T_{i}$ be net trade, $X_{i}$ be output and $D_{i}$ be absorption in sector $i$. Then,

$$
T_{i}=X_{i}-D_{i}
$$

i.e. our net offer is just output less absorption in that sector. We now need to see how that net offer will change at the initial prices if a non-uniform inflow of factors changes sectoral output, GDP, and absorption. For simplicity, we assume that absorption is homothetic, so that at initial prices, the inflow of factors affects the scale of absorption, but not its composition. Keeping in mind that we are looking at discrete changes, we need only take differences in our net offer equation. Let $s_{i} \equiv \frac{X_{i}}{G D P_{i}}$ be defined to be the ratio of output in sector i to GDP, and a circumflex, ${ }^{\wedge}$, represent a proportional change. In Appendix A, we show that the change can be examined as follows:

$$
\Delta T_{i}=X_{i} \hat{s}_{i}+T_{i} \widehat{G D P}+X_{i} \hat{s}_{i} \widehat{G D P}
$$

This differenced equation has three terms. The first is a Composition Effect - reflecting the fact that even at the original GDP, there is a change in the share of output in sector $i$. The second is a Size Effect - reflecting the fact that even if the inflow of factors had no impact on the composition of output, the simple scaling-up of output would raise our net offer. Finally, because of the discrete changes, there is also an interaction between the scale and composition changes that need not be small. 
The starting point for the empirical implementation of this equation is the excellent work of Harrigan (1997). Harrigan builds a full general equilibrium HeckscherOhlin-Ricardo model of global production and then obtains precise estimates of the effects of productivity and endowments on the production of the various manufacturing sectors. The parameter estimates that Harrigan derives are exactly what we need in order to understand how changes in capital and low, medium, and high-skill labor will affect US exports.

Harrigan's point estimates tell us how much a given percentage change in a particular factor will change the value-added share of a particular sector in GDP. By multiplying Harrigan's coefficient estimates (from Table 5 of his paper) by the changes in US factor supplies implied by migration, we obtain estimates for how much each sector's value added share of GDP should change as a result of migration. The only remaining issue is that trade is the difference between production and absorption, not value added and absorption. We will assume that the percentage change in a sector's share of value added is the same as its percentage change in output. Thus, we can use Harrigan's coefficients to calculate $\hat{s}_{i}$ and so to implement the model of the change in the US net offer embodied in equation $(21) .{ }^{14}$ Since the last CPS data on the composition of foreign-born workers is from 1994, we will have to assume that this did not change appreciably by 1998. Performing this calculation for the US reveals that the inflows of factors into the US caused the biggest expansions in US net offers in processed food, apparel, and industrial machinery and contractions in paper, chemicals, and metals. We then calculate $\Delta T_{i}$ by summing the various terms of equation (21).

\footnotetext{
${ }^{14}$ In calculating the terms of trade changes, we are limited to using the sectors employed by Harrigan. This is less than the full universe of sectors (cf. Harrigan 1997). Implicitly we are obliged to assume that terms of trade effects in excluded sectors match the average for included sectors.
} 
Assessing the impacts of these changes in net offers on prices requires some additional assumptions and modeling. $\Delta T_{i}$ must be accommodated by adjustments in the prices of exports and imports. We model this as follows. Assume that price changes in US goods map into export and import prices according to the following equations:

$$
\begin{gathered}
\frac{\Delta E_{i}}{E_{i}}=\varepsilon_{i}^{E} \frac{\Delta p_{i}}{p_{i}} \\
\frac{\Delta M_{i}}{M_{i}}=\varepsilon_{i}^{M} \frac{\Delta p_{i}}{p_{i}}
\end{gathered}
$$

where $E_{i}$ and $M_{i}$ are US exports and imports in sector $i, \varepsilon_{i}^{E}\left(\varepsilon_{i}^{M}\right)$ is the elasticity of US exports (imports), and $p_{i}$ is the relative price of US to foreign goods in the sector. ${ }^{15} \mathrm{We}$ can then write the impact of a change in the US net offer on prices as,

$$
\Delta T_{i}=\Delta E_{i}-\Delta M_{i}=\left(\varepsilon_{i}^{E} E_{i}-\varepsilon_{i}^{M} M_{i}\right) \frac{\Delta p_{i}}{p_{i}}
$$

or

$$
\frac{\Delta T_{i}}{\left(\varepsilon_{i}^{E} E_{i}-\varepsilon_{i}^{M} M_{i}\right)}=\frac{\Delta p_{i}}{p_{i}}
$$

Equation (25) gives us a mapping between changes in net offers and changes in US export prices. Using data on sectoral export and import elasticities taken from Deardorff and Stern (1986) we can estimate the impact of these changes in net offers on prices.

Once again we are faced with the ambiguity of whether a certain percentage change in the relative price of US exports is due to export or import prices changes. Here again we

\footnotetext{
${ }^{15}$ US Import demand elasticities were taken from Table 3.2 pp. $42-43$ of Deardorff and Stern (1986). US export elasticities were based on Table 3.2 and recalculated according to Deardorff and Stern's methodology (equations A.1.25 and A.1.32) with 1994 data.
} 
assume that half of the change is due to export price movements and half due to import price movements. We calculate the change in the terms of trade as

$$
\text { Change in Terms of Trade }=\frac{1}{2} \sum_{i} \frac{\Delta p_{i}}{p_{i}}\left(\frac{E_{i}}{E}+\frac{M_{i}}{M}\right)
$$

where $E$ and $M$ denote aggregate US exports and imports. Using equation (26), we find that factor composition effects imply that the US terms of trade deteriorated by an additional $1.5 \%$. This implies an additional loss for the US of 12.5 billion dollars, which brings the aggregate income loss up to 80 billion or 0.9 percent of GDP. ${ }^{16}$

\section{Magnitude of Losses}

We have now provided an approach to calculating the impact of migration on the income of US natives in two steps. The first step focuses on pure scale effects in a world in which US output is a function of the capital stock and aggregate labor and then applies the trade elasticity estimates of Acemoglu and Ventura (2002). The second step supplements this by considering a world in which output is divided into multiple industries and labor is disaggregated according to educational attainment. The impact of factors on output levels and composition is based on Harrigan (1997) and the sectoral trade elasticities are drawn from Deardorff and Stern (1986). It is worth noting that the latter experiment, in which some sectors expand and others contract in relative terms, could in principle have led to improvements in the US terms of trade.

The results from these experiments suggest that the resulting terms of trade losses are approximately $\$ 80$ billion in 1998 . Of this, approximately 90 percent of the loss

\footnotetext{
${ }^{16}$ Ideally, we would like to have calculated the impact of changing factor ratios on output in the rest of the world. Unfortunately, we don't have consistent data on value added by industry that matched the export data, so we did not do this calculation.
} 
would be borne by US natives, for total income losses from migration of approximately $\$ 72$ billion in the same year. These represent losses of approximately 0.8 percent of GDP annually.

These are big numbers. These losses to US natives from factor immigration are approximately equivalent to Feenstra's (1992) estimate of the annual deadweight loss to the US from all trade protection. It is approximately two to three times Alvarez and Jermann's (2000) estimate of the average annual cost of business cycles to consumers in the postwar period. ${ }^{17}$ In other words, immigration (labor and capital together) is about as costly to the US as all trade protection and two to three times as costly as business cycles!

\section{Robustness of Estimates}

This paper asks us to re-think conventions of estimating the impact of factor migration on the incomes of US natives. And it concludes that the impact is large and negative. Inevitably, to make such calculations, one is obliged to make important assumptions about the appropriate underlying model. And it is equally inevitable that we should want to think hard about how reasonable those assumptions are and if sensible changes would affect the conclusions in an important way.

One key assumption is that the US economy as a whole displays constant returns to scale. If instead it displayed increasing returns in the aggregate, then the conclusions might be attenuated or even reversed. Some early work has argued that there may be aggregate increasing returns, as in Domowitz, Hubbard and Petersen (1988) and Hall (1990). However, Basu and Fernald (1997) have argued that standard approaches of

\footnotetext{
${ }^{17}$ It's also worth noting that a main point of the Alvarez and Jermann paper is that they find large costs of the business cycle relative to the calculations of Lucas (1987).
} 
estimating aggregate increasing returns are severely biased upwards. The reason is simple. If sectors that experience positive productivity shocks also expand output, then there will be a positive correlation between productivity and the size of sectors in an economy. Using US data, Basu and Fernald show that although the aggregate data may appear to exhibit increasing returns, this is simply an artifact of the aggregation bias. Most industries in the US seem to exhibit constant or even decreasing returns. Similarly, using plant level data Baily, Hulten, and Campbell (1992) found that most plants operated using constant returns to scale technology. Based on these results, we think that the baseline assumption of aggregate constant returns to scale is reasonable.

One can turn the question around and ask how big one needs to believe increasing returns need to be in order to offset the terms of trade effect. The Acemoglu and Ventura estimate coupled with the importance of trade in the US suggests that elasticity of per capita income with respect to size is -0.057 . However, given that our previous estimate based on actual factor migration suggested that an 11.8 percent increase in the US implied a 1.9 percent contraction in the rest of the world, we estimate that the elasticity of output with respect to size must be in excess of 1.07 in order for factor migration not to lower the income of US natives. 
A second issue is whether there is something unique about immigration that selects for those who contribute unusually to a society and its economy. We don't have a final answer. There is no doubt that some immigrants to the US have contributed enormously to particular fields (e.g. economics) and industries (e.g. high tech in Silicon Valley). It is less clear what would have happened in the counterfactual. We would simply note that Borjas (1999, pp. 96-98) is skeptical, arguing there is "no empirical evidence" that the contributions of immigrants are outsize to their numbers. ${ }^{18}$

A third issue is that so far we have been treating immigrant labor as identical to domestic labor. It is worth revisiting this in a manner suggested by our model of Section III. Immigrants typically earn less than domestic workers of similar educational levels. If this reflects differences in productivity, say due to immigrants' poor English ability, then they will not replace native-born workers one for one. One reasonable approximation for how much less productive immigrants are is given by the differential between the wages paid to immigrants and the wages paid to native born workers after controlling for education, age, and region of employment. Borjas (1995) estimates this gap to be 10 percent in 1990. Indeed, if we assume that one immigrant generates only 90 percent of the output of a native-born worker, the welfare loss for natives falls from 72 billion dollars to 68 billion dollars when we control for both aggregate and sectoral effects, and less if we think that immigrants into the US are higher quality than the average worker in the rest of the world. We therefore conclude that adjustments for

\footnotetext{
${ }^{18}$ Indeed, one of the classic contributions of Borjas (1985) was to challenge the results of Chiswick (1978). Chiswick, examining a cross section, concluded not only that immigrants closed the wage gap with natives but actually overtook them, with the supposed explanation being selection for unusually clever immigrants from among the foreign born. Borjas showed that such results in the cross section would appear even without any convergence if there were declining average quality of cohorts, a feature of the US time series.
} 
unobserved immigrant quality are likely to have only small impacts on our point estimates.

\section{Conclusions}

This paper provides an alternative to the conventional account of the immigration of factors to the United States and their impact on native incomes. In the conventional account, such migration is considered one factor at a time holding all others fixed. While the reasons for migration are not always fully articulated, usually the implicit assumption is that it is a story of relative scarcity of factors, as in simple non-Factor Price Equalization versions of the Heckscher-Ohlin trade model. In this conventional model, the movement of productive factors raises world income and these income gains are shared between natives of both source and recipient countries. In effect, the conventional account holds that there are mutual gains from migration very much in parallel to the conventional gains from trade.

We instead argue for applying a Ricardian framework, in which factor migration is motivated by the technological superiority of the United States. Such a model has important positive and normative differences. It implies that all factors should seek to enter the country with a technological advantage. Indeed, we observe that low-skill labor, high-skill labor, and capital all have important inflows to the United States. While, as in the conventional model, the flow of factors raises world income, there is nonetheless a strong contrast. Instead of these gains accruing in part to natives of both countries, here more than all of the gains accrue to natives of the source country. Natives of the United States, as recipient country, suffer income losses. 
We also develop a baseline empirical exercise that quantifies these losses in two steps. The first step focuses on a one-sector macro model with nationally differentiated products that may be thought of as a melding of a simple Ricardian model with the world $A K$ trade model of Acemoglu and Ventura (2002). The second enriches this by disaggregating both labor and product types, allowing the factor flows to affect not only the level but also the composition of production and trade. The empirical exercise implies that the combination of labor immigration and net capital inflows is very costly for US native incomes. In 1998 , these losses would have been approximately $\$ 72$ billion. This is roughly equivalent to Feenstra's (1992) calculation of losses from all US protection or two to three times what Alvarez and Jermann (2000) calculate as the per annum cost of the US business cycle.

It is both natural and important that this paper stress the novel elements of our analysis - in particular the result that US natives may lose a great deal of income from these factor flows. However, it is likewise important to stress some cautions in applying this analysis and indicate some directions in which additional research is warranted. First, as in the conventional model, the flow of factors here enhances world efficiency. In principle, were it feasible and desirable, lump sum redistribution could yield Pareto gains. Even if such redistribution is not undertaken, factor migration provides first order gains both to migrating factors and to those that remain in the source country (the latter via improved terms of trade) - gains which may far exceed the cost to US natives. In this respect, it may be looked on as a contribution to world welfare of the openness of the US to factor migration. Second, our focus on the impact on native incomes naturally cannot take any account of benefits that may accrue to a society from living in an environment 
enriched by immigrants in ways not mediated by the market. Third, it is worth examining more closely the contributions of immigrants particularly to knowledge-intensive sectors, whether in Silicon Valley or the halls of academia, to identify contributions to income that may surpass those identified in this paper. Finally, one may in principal identify a large number of other contributions by immigrants. Follow-on work should aim to quantify these contributions. 


\section{REFERENCES}

Acemoglu, Daron; Ventura, Jaume, "The World Income Distribution," Quarterly Journal of Economics, May 2002

Alvarez, Fernando and Urban Jermann (2000) "Using Asset Prices to Measure the Cost of Business Cycles, University of Chicago, mimeo.

Baily, Martin Neil; Hulten, Charles; Campbell, David, "Productivity Dynamics in Manufacturing Plants," Brookings Papers on Economic Activity, vol. 0, no. 0, Microeconomics 1992, pp. 187-249

Basu, Susanto; Fernald, John G, "Returns to Scale in U.S. Production: Estimates and Implications," Journal of Political Economy, vol. 105, no. 2, April 1997, pp. 24983

Bhagwati, Jagdish. 1958. "Immiserizing Growth: A Geometrical Note," Review of Economic Studies 25, (June), pp. 201-205

Borjas, George J (2001) "Does Immigration Grease the Wheels of the Labor Market?" Brookings Papers on Economic Activity, 2001, pp. 69-119.

Borjas, George J (1999) Heaven's Door: Immigration Policy and the American Economy, Princeton: Princeton University Press.

Borjas, George J (1995) “The Economic Benefits from Immigration,” Journal of Economic Perspectives, vol. 9, no. 2, Spring 1995, pp. 3-22

Borjas, George J. (1995) "The Economic Analysis of Immigration," in The New Economics of Human Behavior, edited by Mariano Tommasi and Kathryn Ierulli, Cambridge University Press, 1995, pp. 27-39.

Borjas, George J (1994) “The Economics of Immigration,” Journal of Economic Literature, vol. 32, no. 4, December 1994, pp. 1667-1717.

Borjas, George J (1999) "The Economic Analysis of Immigration," in The Handbook of Labor Economics, Volume 3A, edited by Orley Ashenfelter and David Card, North-Holland, pp. 1697-1760.

Borjas, George J, Richard B. Freeman and Lawrence F. Katz (1997) "How Much Do Immigration and Trade Affect Labor Market Outcomes? Brookings Papers on Economic Activity, 1997, pp. 1-67.

Bowen, Harry P; Leamer, Edward E; Sveikauskas, Leo, "Multicountry, Multifactor Tests of the Factor Abundance Theory," American Economic Review, vol. 77, no. 5, December 1987, pp. 791-809. 
Chiswick, Barry R, "The Effect of Americanization on the Earnings of Foreign-born Men," Journal of Political Economy, vol. 86, no. 5, Oct. 1978, pp. 897-921

Davis, Donald R; Weinstein, David E, "What Role for Empirics in International Trade?" in Ronald Findlay, Lars Jonung, Mats Lundahl, eds., Bertil Ohlin: A Centennial Celebration, 1899-1999, Cambridge: MIT Press, 2002

Deardorff, Alan V. and Stern, Robert (1986) The Michigan Model of World Production and Trade: Theory and Applications, Cambridge: The MIT Press.

Domowitz, Ian; Hubbard, R Glenn; Petersen, Bruce C, "Market Structure and Cyclical Fluctuations in U.S. Manufacturing," Review of Economics and Statistics, vol. 70, no. 1, February 1988 , pp. 55-66

Dornbusch, Rudiger; Fischer, Stanley; Samuelson, Paul A, "Comparative Advantage, Trade, and Payments in a Ricardian Model with a Continuum of Goods," American Economic Review, vol. 67, no. 5, Dec. 1977, pp. 823-39

Feenstra (1992) “How Costly is Protection?” Journal of Economic Perspectives, vol. 6, no. 32, pp. 159-178.

Findlay, Ronald (1982) "International Distributive Justice: A Trade Theoretic Approach," Journal of International Economics, vol. 13, no. 1-2, August 1982, pp. 1-14

Friedberg, Rachel M; Hunt, Jennifer, "The Impact of Immigrants on Host Country Wages, Employment and Growth," Journal of Economic Perspectives, vol. 9, no. 2, Spring 1995, pp. 23-44

Grossman, Gene M, “The Gains from International Factor Movements," Journal of International Economics, vol. 17, no. 1-2, August 1984, pp. 73-83

Hall, Robert E. (1990) "Invariance Properties of Solow's Productivity Residual," in Diamond, Peter ed. Growth/Productivity/Unemployment: Essays to Celebrate Bob Solow's Birthday, Cambridge: The MIT Press.

Hall, Robert E. and Charles I. Jones (1996) “The Productivity of Nations,” NBER Working Paper \#5812.

Harrigan, James, "Technology, Factor Supplies, and International Specialization: Estimating the Neoclassical Model," American Economic Review, vol. 87, no. 4, September 1997, pp. 475-94.

Hendricks, Lutz, "How Important is Human Capital for Development? Evidence From Immigrant Earnings," American Economic Review, vol. 92, no. 1, March 2002, pp. 198-219. 
Immigration and Naturalization Service (2002) Statistical Yearbook of the Immigration and Naturalization Service, 1999, Washington D.C.: US Government Printing Office.

International Monetary Fund (2000) International Financial Statistics (CD ROM), Washington: Publishing Services International Monetary Fund.

Islam, Nazrul (1995) “Growth Empirics: A Panel Data Approach,” Quarterly Journal of Economics 110, pp. 1127-70.

Islam, Nazrul (2001) "Different Approaches to International Comparison of Total Factor Productivity," in Hulten, Charles R., Edwin R. Dean, and Michael J. Harper, eds. New Developments in Productivity Analysis, Chicago: University of Chicago Press, pp. 465-508.

Jorgenson, Dale W. and Masahiro Kuroda, (1990) "Bilateral Models of Production for Japanese and US Industries," in Hulten, Charles ed. Productivity Growth in Japan and the United States, Chicago: University of Chicago Press.

Lalonde, Robert J; Topel, Robert H., "Economic Impact of International Migration and the Economic Performance of Migrants," in Rosenzweig, Mark R; Stark, Oded, eds. Handbook of population and family economics. Volume 1B. 1997, pp. 799850, New York: Elsevier Science, North-Holland

Lucas, Robert E. (1987) Models of Business Cycles, New York: Basil Blackwell.

MacDougall, G.D.A. (1960) "The Benefits and Costs of Private Investment From Abroad," Economic Record 36: 13-35.

Organization of Economic Cooperation and Development (2001) Trends in International Migration, Paris: OECD Publication Service.

Razin, Assaf and Sadka, Efraim (2001) Labor, Capital and Finance: International Flows, New York: Cambridge U. Pr.

Trefler, Daniel (1997) "Natives and Immigrants in General Equilibrium," NBER Working Papers \#6209, October.

Wong, Kar-Yiu (1995) International Trade in Goods and Factor Mobility, Cambridge, MA: MIT Pr.

World Bank (1999) The World Development Report 1999, Oxford: Oxford University Press. 


\section{Table 1}

\begin{tabular}{|c|c|c|c|c|c|}
\hline Country & Index & & & & \\
\hline Africa & & Asia & & Americas & \\
\hline Algeria & 18.64 & Bangladesh & 13.27 & Argentina & 25.92 \\
\hline Angola & 13.27 & Burma & 8.63 & Bolivia & 16.86 \\
\hline Benin & 7.07 & Hong Kong & 153.73 & Brazil & 41.90 \\
\hline Botswana & 20.39 & India & 7.07 & Canada & 104.08 \\
\hline Burundi & 6.46 & Israel & 61.88 & Chile & 22.54 \\
\hline Cameroon & 16.04 & Japan & 78.66 & Colombia & 28.65 \\
\hline Central African Republic & 5.56 & Jordan & 25.92 & Costa Rica & 38.29 \\
\hline Chad & 4.20 & South Korea & 38.29 & Dominican Republic & 21.44 \\
\hline Congo & 12.00 & Malaysia & 38.29 & Ecuador & 23.69 \\
\hline Egypt & 15.26 & Nepal & 12.00 & El Salvador & 24.66 \\
\hline Ethiopia & 7.81 & Pakistan & 19.40 & Guatemala & 31.35 \\
\hline Ghana & 5.34 & Philippines & 18.64 & Haiti & 11.42 \\
\hline Ivory Coast & 16.86 & Singapore & 86.07 & Honduras & 12.62 \\
\hline Kenya & 7.07 & Sri Lanka & 15.26 & Jamaica & 16.86 \\
\hline Liberia & 5.84 & Syria & 46.30 & Mexico & 48.68 \\
\hline Madagascar & 8.63 & Thailand & 24.66 & Nicaragua & 30.12 \\
\hline Malawi & 5.84 & Europe & & Panama & 28.65 \\
\hline Mali & 5.56 & Austria & 67.71 & Paraguay & 32.96 \\
\hline Mauritania & 4.60 & Belgium & 78.66 & Peru & 32.96 \\
\hline Mauritius & 18.64 & Denmark & 74.83 & Trinidad & 61.88 \\
\hline Morocco & 31.35 & Finland & 50.66 & Uruguay & 38.29 \\
\hline Mozambique & 12.00 & France & 78.66 & United States & 100.00 \\
\hline Niger & 7.81 & Germany & 67.71 & Venezuela & 53.26 \\
\hline Nigeria & 8.98 & Greece & 38.29 & Australia and Other & \\
\hline Rwanda & 6.46 & Ireland & 38.29 & Australia & 58.86 \\
\hline Senegal & 10.97 & Italy & 58.86 & New Zealand & 58.86 \\
\hline Sierra Leone & 7.43 & Netherlands & 71.18 & Papua New Guinea & 17.73 \\
\hline Somalia & 3.62 & Norway & 86.07 & & \\
\hline South Africa & 38.29 & Portugal & 34.65 & & \\
\hline Sudan & 6.14 & Spain & 78.66 & & \\
\hline Tanzania & 4.37 & Sweden & 71.18 & & \\
\hline Togo & 7.07 & Switzerland & 61.88 & & \\
\hline Tunisia & 27.25 & Turkey & 27.25 & & \\
\hline Uganda & 10.44 & United Kingdom & 71.18 & & \\
\hline Zaire & 4.37 & & & & \\
\hline Zambia & 4.20 & & & & \\
\hline Zimbabwe & 10.44 & & & & \\
\hline
\end{tabular}

\section{Country Level Total Factor Productivity (US =100) Index}

Africa

Algeria

Benin

Burundi

Cameroon

4.20 South Korea

5.26 Nepal

7.81 Pakistan

Philippines

7.07 Sri Lanka

5.84 Syria

5.84 Europe

5.56 Austria

31.35 Finland

2.00 France

8.98 Greece

898 Greece

0.97 Italy

7.43 Netherlands

0.44 $\begin{array}{rlr}13.27 & \text { Argentina } & 25.92 \\ 8.63 & \text { Bolivia } & 16.86\end{array}$

53.73 Brazil $\quad 41.90$

61.88 Chile 22.54

78.66 Colombia 28.65

38.29 Dominican Republic 21.44

12.00 El Salvador $\quad 24.66$

19.40 Guatemala $\quad 31.35$

86.07 Honduras $\quad 12.62$

15.26 Jamaica $\quad 16.86$

46.30 Mexico 48.68

30.12

8.65

32.96

61.88

38.29

53.26

58.86

8.86

17.73 


\section{Table 2}

\section{Capital and Legal immigrant inflows into the US}

\begin{tabular}{|c|c|c|c|}
\hline & $\begin{array}{c}\text { Average Number of } \\
\text { Legal Immigrants per } \\
\text { Year }\end{array}$ & $\begin{array}{l}\text { Percent of Population } \\
\text { Growth Due to } \\
\text { Immigration }\end{array}$ & $\begin{array}{c}\text { Average Annual Net } \\
\text { Capital Inflows As a } \\
\text { Percent of Gross } \\
\text { Fixed Capital } \\
\text { Formation }\end{array}$ \\
\hline 1950-1959 & 249,927 & $9 \%$ & \\
\hline 1960-1969 & 321,365 & $14 \%$ & \\
\hline 1970-1979 & 423,232 & $21 \%$ & $-0.76 \%$ \\
\hline 1980-1991 & 807,989 & $38 \%$ & $6.84 \%$ \\
\hline 1992-1998 & 825,414 & $36 \%$ & $12.81 \%$ \\
\hline
\end{tabular}

Source: INS and IMF. We include 1990 and 1991 in the decade with the 1980's because an amnesty program produced very large recorded immigration inflows in the late 1980's and early 1990's.

\section{Table 3}

Educational Attainment of the Labor Force in 1994 by Place of Birth in Percent

$\begin{array}{ccc}\begin{array}{c}\text { Less than } 12 \text { Years } \\ \text { of Education }\end{array} & \begin{array}{c}12-15 \text { Years of } \\ \text { Education }\end{array} & \begin{array}{c}16 \text { or more years of } \\ \text { Education }\end{array}\end{array}$

$\begin{array}{llll}\text { Foreign Born } & 33.2 & 38.0 & 28.8\end{array}$

$\begin{array}{llll}\text { Native Born } & 12.5 & 55.4 & 32.0\end{array}$

$\begin{array}{llll}\text { Total } & 14.8 & 53.5 & 31.7\end{array}$

Source: CPS 


\section{Figure 1}

The Equilibrium with No Migration

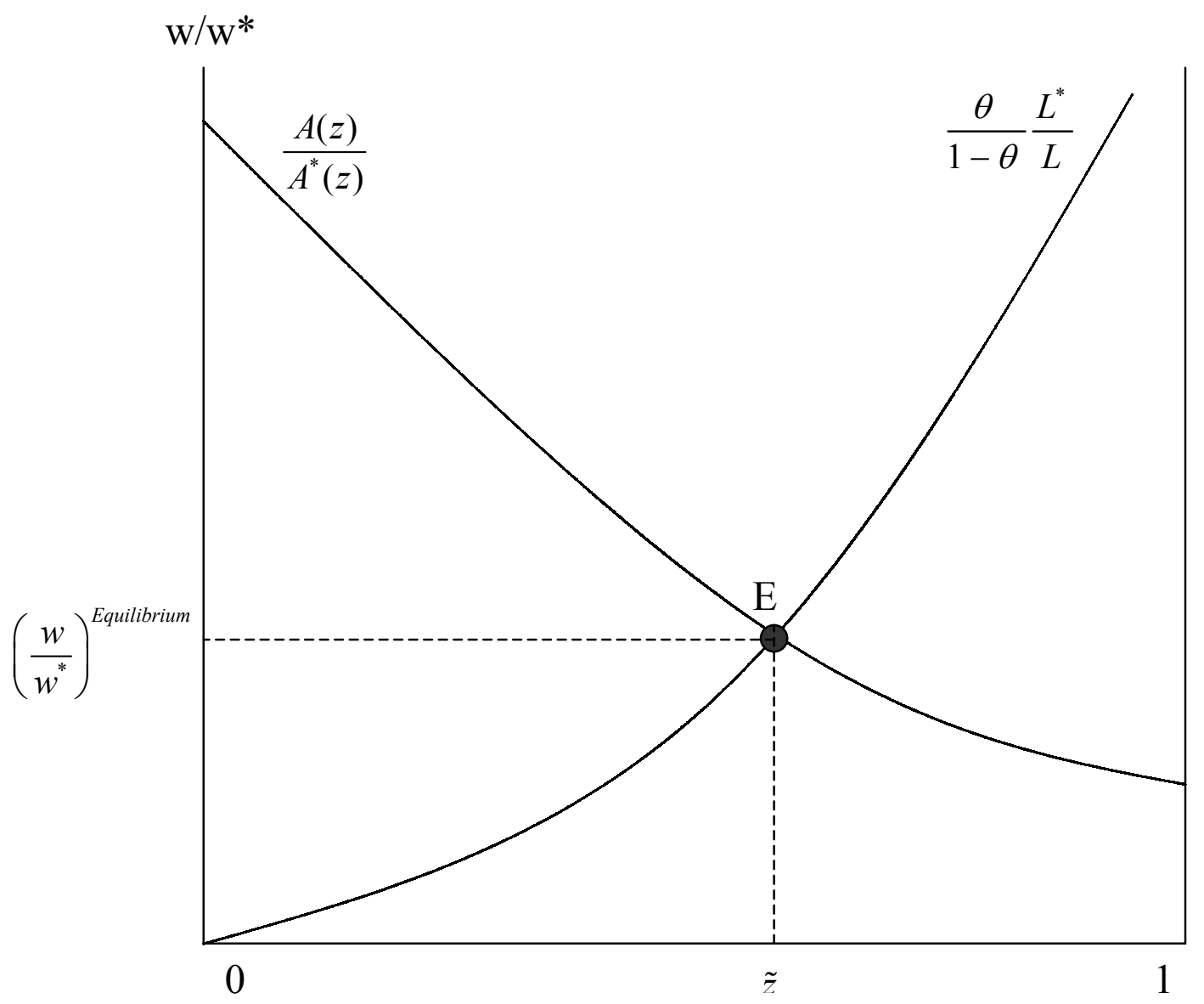


Figure 2

Equilibrium with Migration When Both Have

Superiority in an Interval of Goods

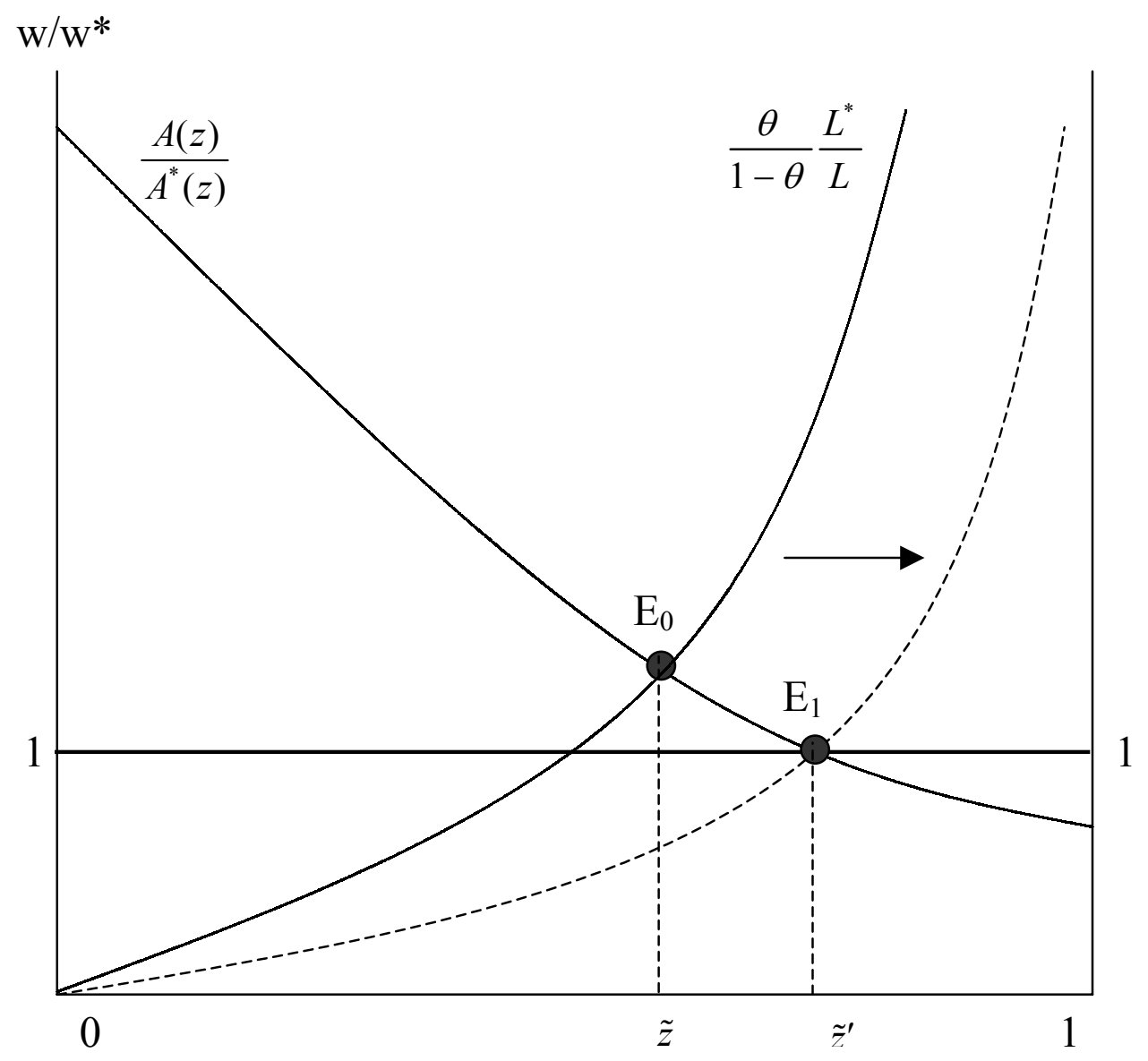




\section{Figure 3}

Equilibrium with Migration When One Country

Has Superior Technology in All Goods

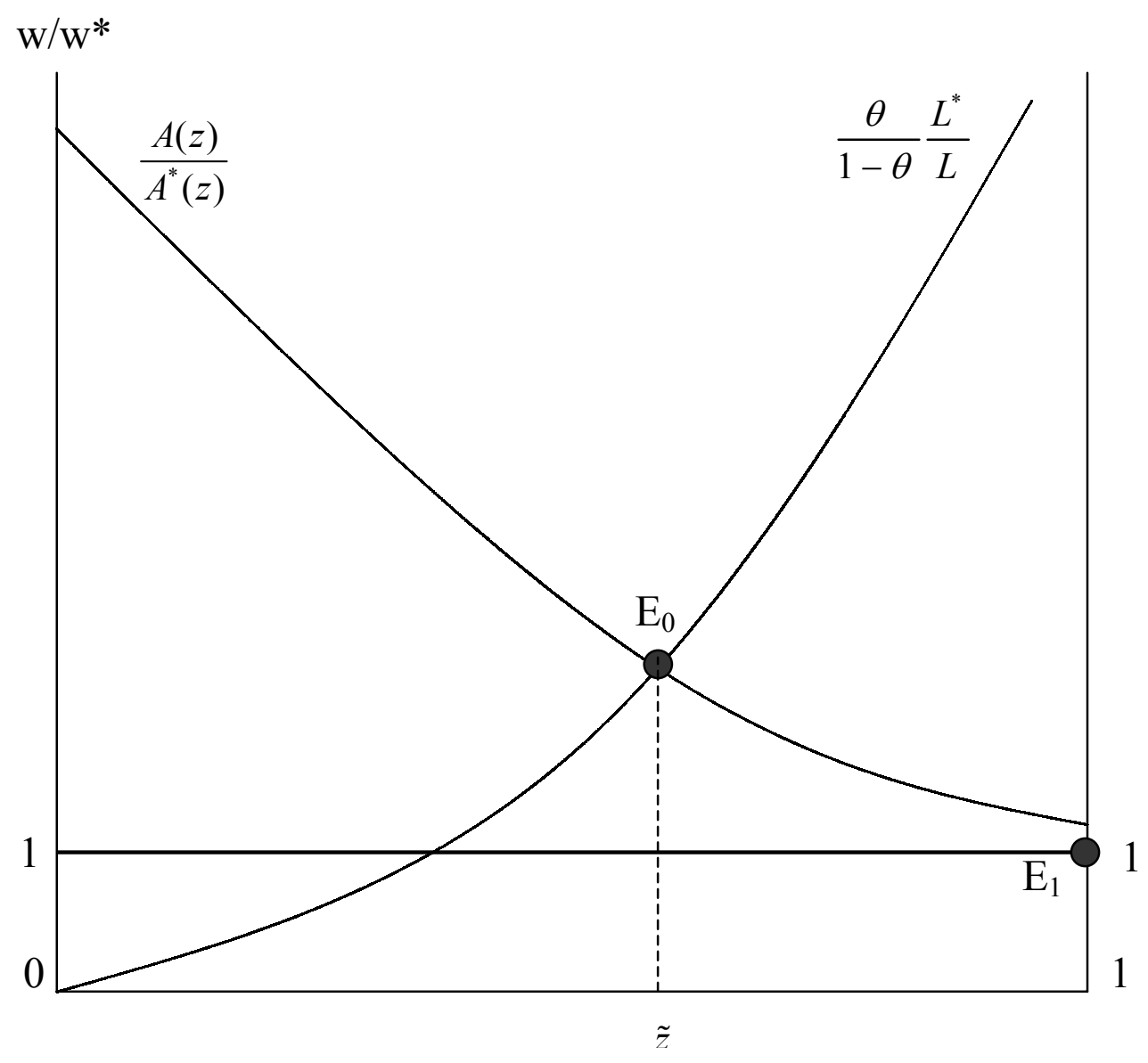


Figure 4

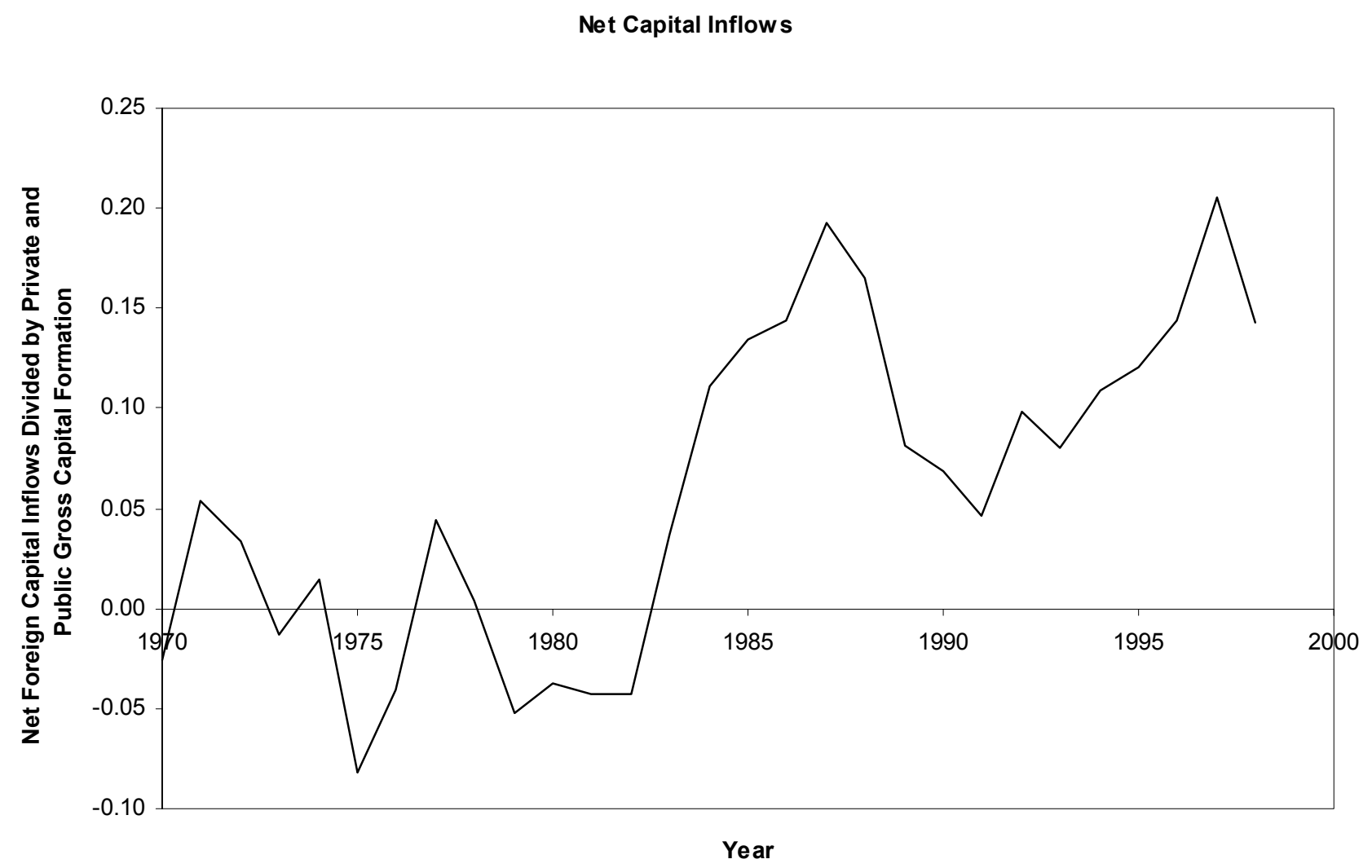




\section{Appendix A}

In this appendix we show how we derived equation (21). If we express equation (20) in changes, we obtain

$$
\Delta T_{i}=\Delta X_{i}-\Delta D_{i}
$$

If we make the standard assumption of homothetic preferences, we have

$$
\Delta D_{i}=D_{i} \frac{\Delta G D P}{G D P}=D_{i} \widehat{G D P}
$$

where a circumflex indicates a percentage change. We can also decompose the change of output according to the following formula:

$$
X_{i}=\frac{X_{i}}{G D P} G D P \Rightarrow \Delta X_{i}=G D P\left[\Delta \frac{X_{i}}{G D P}\right]+\frac{X_{i}}{G D P} \Delta G D P+\left[\Delta \frac{X_{i}}{G D P}\right] \Delta G D P
$$

where the last term would be zero if the changes were not discrete. After a little manipulation we obtain:

$$
\Delta X_{i}=X_{i}\left(\frac{\Delta \frac{X_{i}}{G D P}}{\frac{X_{i}}{G D P}}\right)+X_{i} \frac{\Delta G D P}{G D P}+X_{i}\left(\frac{\Delta \frac{X_{i}}{G D P}}{\frac{X_{i}}{G D P}}\right) \frac{\Delta G D P}{G D P}
$$

or

$$
\Delta X_{i}=X_{i} \hat{s}_{i}+X_{i} \widehat{G D P}+X_{i} \hat{s}_{i} \widehat{G D P}
$$

Inserting equations (28) and (31) into equation (27) and rearranging terms produces equation (21) in the text:

$$
\Delta T_{i}=X_{i} \hat{s}_{i}+T_{i} \widehat{G D P}+X_{i} \hat{s}_{i} \widehat{G D P}
$$

